\title{
Insulin resistance, selfish brain, and selfish immune system: an evolutionarily positively selected program used in chronic inflammatory diseases
}

\author{
Rainer H Straub*
}

\begin{abstract}
Insulin resistance (IR) is a general phenomenon of many physiological states, disease states, and diseases. IR has been described in diabetes mellitus, obesity, infection, sepsis, trauma, painful states such as postoperative pain and migraine, schizophrenia, major depression, chronic mental stress, and others. In arthritis, abnormalities of glucose homeostasis were described in 1920; and in 1950 combined glucose and insulin tests unmistakably demonstrated IR. The phenomenon is now described in rheumatoid arthritis, systemic lupus erythematosus, ankylosing spondylitis, polymyalgia rheumatica, and others. In chronic inflammatory diseases, cytokine-neutralizing strategies normalize insulin sensitivity. This paper delineates that IR is either based on inflammatory factors (activation of the immune/ repair system) or on the brain (mental activation via stress axes). Due to the selfishness of the immune system and the selfishness of the brain, both can induce IR independent of each other. Consequently, the immune system can block the brain (for example, by sickness behavior) and the brain can block the immune system (for example, stressinduced immune system alterations). Based on considerations of evolutionary medicine, it is discussed that obesity per se is not a disease. Obesity-related IR depends on provoking factors from either the immune system or the brain. Chronic inflammation and/or stress axis activation are thus needed for obesity-related IR. Due to redundant pathways in stimulating IR, a simple one factor-neutralizing strategy might help in chronic inflammatory diseases (inflammation is the key), but not in obesity-related IR. The new considerations towards IR are interrelated to the published theories of IR (thrifty genotype, thrifty phenotype, and others).
\end{abstract}

\section{Introduction}

In 1916, the diabetologist Elliott P Joslin recognized that 'hyperglycemic situations appear after infectious diseases, painful conditions such as gall stones, and trauma' [1]. In 1920, Pemberton and Foster described impaired glucose regulation in soldiers with arthritis [2]. In 1924, Rabinowitch observed that diabetic patients need much more insulin during infection [3]. In 1929, Root summarized the presence of an inadequately high need for insulin in different diseases, and he called the phenomenon 'insulin resistance' (IR) [4].

Over the last century, IR was found in physiological states, disease states, and diseases such as diabetes mellitus, obesity, infection, sepsis, arthritis of different

*Correspondence: rainer.straub@ukr.de

Laboratory of Experimental Rheumatology and Neuroendocrine Immunology, Division of Rheumatology, Department of Internal Medicine, University Hospital, 93042 Regensburg, Germany types (including rheumatoid arthritis (RA)), systemic lupus erythematosus, ankylosing spondylitis, trauma, painful states such as postoperative pain and migraine, schizophrenia, major depression, and mental stress, to name the most important (chronology of events is summarized in Table 1). IR thus seems to be present in many diseases states outside the field of diabetology or more specifically - exterior of inherited IR syndromes (called the type A syndrome of IR) and also beyond autoantibodies to insulin or insulin receptor (type $B$ syndrome of IR) [5].

When considering these diseases and disease states, one observes two major clusters of clinical entities that are linked to IR: inflammation with an activated immune/ repair system; and increased mental activation. In this clearly defining distinction, obesity and type 2 diabetes mellitus (T2D) can be integrated into the first cluster due the inflammatory aspect of IR in these entities [6-9]. However, obesity and consequently T2D might also be integrated into the latter cluster because chronic mental stress is a well-known forerunner of obesity in 
Table 1. History of insulin resistance from different perspectives of research in the fields of diabetology, infection/ inflammation, pain, mental activation, trauma, and rheumatology

\begin{tabular}{|c|c|c|c|}
\hline Year & Author & Phenomena & Reference \\
\hline 1916 & Joslin & Hyperglycemia in infectious diseases, ${ }^{a}$ painful gallstones, ${ }^{b}$ trauma ${ }^{c}$ & [1] \\
\hline 1920 & Pemberton and Foster & Impaired glucose regulation in soldiers with arthritis & [2] \\
\hline 1924 & Rabinowitch & Enormous doses of insulin needed in infected diabetic patients ${ }^{a}$ & [3] \\
\hline 1929 & Root & IR in the context of different diseases ${ }^{\mathrm{a}, \mathrm{b}, \mathrm{c}}$ & [4] \\
\hline 1936 & Himsworth and Kerr & Insulin-sensitive and insulin-insensitive diabetes & [106] \\
\hline 1938 & Thomsen & Traumatic diabetes ${ }^{c}$ & {$[107]$} \\
\hline 1938 & Warren & $\beta$-cell defects in older longstanding diabetic patients & $\ln [108]$ \\
\hline 1950 & Liefmann & IR in rheumatoid arthritis (combined glucose and insulin test) ${ }^{\mathrm{a}}$ & [16] \\
\hline 1956 & Arendt and Pattee & IR in obese subjects & [109] \\
\hline 1957 & Collins & IR in schizophrenia ${ }^{d}$ & [110] \\
\hline 1960 & Yalow and Berson & IR in diabetic subjects (high glucose despite high insulin) & {$[24]$} \\
\hline 1963 & Randle and colleagues & Fatty acids support IR & [25] \\
\hline 1965 & van Praag and Leijnse & Major depression induces $\mathbb{R}^{d}$ & [111] \\
\hline 1965 & Butterfield and Wichelow & Forearm insulin sensitivity test & [112] \\
\hline 1970 & Shen and colleagues & Quadruple insulin sensitivity test & [113] \\
\hline 1979 & DeFronzo and colleagues & $\begin{array}{l}\text { Euglycemic insulin clamp technique in combination with radioisotope turnover, } \\
\text { limb catheterization, indirect calorimetry, and muscle biopsy }\end{array}$ & [114] \\
\hline 1979 & Wolfe & Review: sepsis and trauma induce $\mathbb{R}^{\mathrm{a}, \mathrm{b}, \mathrm{c}}$ & [115] \\
\hline 1982 & Kasuga and colleagues & Insulin induces tyrosine phosphorylation of the insulin receptor & [116] \\
\hline 1982 & Ciraldi and colleagues & Reduced insulin-stimulated glucose uptake in type 2 diabetes & [117] \\
\hline 1984 & Grunberger and colleagues & $\begin{array}{l}\text { Dissociation between normal insulin binding and defective tyrosine kinase activity of } \\
\text { the insulin receptor }\end{array}$ & [118] \\
\hline 1986 & Garvey and colleagues & Hyperinsulinemia induces insulin receptor desensitization & [119] \\
\hline 1987 & Svenson and colleagues & IR in rheumatoid arthritis ${ }^{a}$ & {$[17]$} \\
\hline 1988 & Krieger and Landsberg & Hypertension, hyperinsulinemia, insulin resistance and SNS & [120] \\
\hline 1988 & DeFronzo & Hyperglycemia decreases glucose transport and inhibits beta-cell function (glucotoxicity) & {$[121]$} \\
\hline 1988 & DeFronzo, Reaven & $\begin{array}{l}\text { Increased free fatty acids play key role in IR, } \beta \text {-cell dysfunction, and hepatic } \\
\text { gluconeogenesis (lipotoxicity) }\end{array}$ & {$[121,122]$} \\
\hline 1988 & $\begin{array}{l}\text { Uchita and colleagues, } \\
\text { Greisen and colleagues }\end{array}$ & Pain influences IR via the HPA axis and SNS ${ }^{b}$ & {$[123,124]$} \\
\hline 1992 & Feingold and Grunfeld & Cytokines like TNF play a role in hyperlipidemia and diabetes ${ }^{\mathrm{a}}$ & [125] \\
\hline 1993 & Hotamisligil and colleagues & TNF critically influences $I^{\mathrm{a}}$ & [34] \\
\hline 1994 & Moberg and colleagues & Mental stress induces acute IR in type 1 diabetic patients ${ }^{d}$ & [126] \\
\hline 1996 & Keltikangas and colleagues & Mental stress is accompanied by IR in nondiabetic people ${ }^{d}$ & [127] \\
\hline 1999 & Björntrop & IR as a consequence of exaggerated HPA axis and SNS activation (CNS stress is the trigger) ${ }^{d}$ & {$[28]$} \\
\hline 2000 & Chrousos & Mental stress-induced hypercortisolism induces IR (the pseudo-Cushing state) ${ }^{d}$ & [29] \\
\hline 2000 & Seematter and colleagues & $\begin{array}{l}\text { Mental stress acutely increases insulin-stimulated glucose utilization in healthy lean } \\
\text { humans but not in obese nondiabetic humans }{ }^{d}\end{array}$ & [128] \\
\hline 2004 & Tso and colleagues & $\begin{array}{l}\text { Patients with systemic lupus erythematosus demonstrate IR independent of } \\
\text { autoantibodies to insulin receptor }\end{array}$ & [19] \\
\hline 2005 & $\begin{array}{l}\text { Kiortsis and colleagues, } \\
\text { Stagakis and colleagues }\end{array}$ & $\begin{array}{l}\text { Patients with ankylosing spondylitis and rheumatoid arthritis have } \mathbb{R} \text {, which is } \\
\text { reduced after anti-TNF therapy }{ }^{\mathrm{a}}\end{array}$ & {$[20,44]$} \\
\hline 2007 & Larsen and colleagues & IL-1 ra improved beta-cell secretory function in type 2 diabetic patients (no influence on IR) ${ }^{\mathrm{e}}$ & {$[129]$} \\
\hline 2008 & $\begin{array}{l}\text { Fleischman and colleagues, } \\
\text { Goldfine and colleagues }\end{array}$ & Salsalate improved insulin sensitivity in young obese adults and in type 2 diabetic patients & {$[43,130]$} \\
\hline 2010 & Schultz and colleagues & Patients with rheumatoid arthritis show IR, which can be reduced by blocking IL-6a & {$[45]$} \\
\hline $\begin{array}{l}2012, \\
2014\end{array}$ & $\begin{array}{l}\text { DIAGRAM and colleagues, } \\
\text { Fall and Ingelsson }\end{array}$ & Human gene polymorphisms link both inflammation and metabolic disease & {$[93,131]$} \\
\hline
\end{tabular}

CNS, central nervous system; DIAGRAM, DIAbetes Genetics Replication And Meta-analysis Consortium; HPA, hypothalamic-pituitary-adrenal; IL, interleukin; IR, insulin resistance; OGTT, oral glucose tolerance test; SNS, sympathetic nervous system; TNF, tumor necrosis factor. alnsulin resistance as a consequence of infection or inflammation. 'Insulin resistance as a consequence of pain. Insulin resistance as a consequence of trauma. IInsulin resistance as a consequence of mental activation. eApproved by the US Food and Drug Administration for patients with type 2 diabetes mellitus. 
approximately $40 \%$ of investigated stressed subjects [10-15]. At this point the question is why these two disease clusters are linked to IR, which will be addressed in the present paper.

Since chronic inflammatory diseases (CIDs) such as arthritis were among the first to be linked to IR $[2,16]$, newer work in rheumatology has recognized IR in many CIDs [17-20], cytokine-neutralizing strategies decrease IR in CIDs [20-22], and CID patients are at increased risk to develop T2D [23], the special view from rheumatology to IR is understandable and necessary. The reader will see that IR is not an endocrine disorder per se, but more a disorder of several systems, better tackled from an interdisciplinary standpoint of neuroendocrine immunology.

Features of insulin resistance and pathophysiology Originally, IR was defined as a subnormal biologic response to a certain insulin concentration, whereby the word subnormal already suggests illness. In the late 1950s, Yalow and Berson developed the radioimmunoassay to measure circulating insulin in the blood. In this early paper, they described a state of IR in T2D patients: $\therefore$... [there is a] lack of responsiveness of blood sugar, in the face of apparently adequate amounts of insulin secreted ...' [24]. The classical characteristics of IR are presented in Table 2. Elements given in this table work together to induce clinically observed hyperglycemia and very low density lipoprotein hyperlipidemia (triglycerides) despite elevated insulin levels.

IR is measured by different techniques, whereby the gold standard is the hyperinsulinemic euglycemic clamp and the silver standard is the frequently sampled intravenous glucose tolerance test (Table 3). To study IR or insulin sensitivity in CIDs, simple fasting indices are often used such as the homeostasis model assessment insulin resistance and the Quicki (Table 3), which are adequate when applied in larger clinical studies.

\section{Pathophysiology of insulin resistance - a chronology of models}

The first viable theory on IR was presented by Randle, who suggested that IR in muscle and adipose tissue is based on the glucose-fatty acid cycle [25]. The theory suggested that IR is a consequence of an increased presence of circulating fatty acids and ketone bodies that lead to defects in glucose utilization and an everincreasing insensitivity to insulin. The biochemical principles of this model are still valid and useful today.

Further clarification throughout the 1960s and 1970s came from endocrine diseases that were accompanied by IR. The explanatory power of hormones is particularly obvious in diseases with an overproduction of a distinct glucogenic hormone such as in Cushing's syndrome (cortisol), acromegaly (growth hormone),
Table 2. Classical signs of insulin resistance until 1995 $[5,28,121,122]$

\begin{tabular}{ll}
\hline Structure, organ & Observed change \\
\hline Insulin receptor & Inhibited \\
Insulin receptor signaling cascade & Inhibited \\
Muscle & \\
Glycogen synthase & Inhibited \\
Hexokinase II & Inhibited \\
Pyruvate dehydrogenase & Inhibited \\
Liver & \\
Hepatic glucose production & Stimulated \\
(gluconeogenesis, glycogenolysis) & \\
Insulin clearance & Stimulated \\
Adipose tissue & \\
Free fatty acid mobilization & Stimulated \\
Signs in circulating blood & \\
Hyperglycemia & Yes \\
Hyperlipidemiaa & Yes \\
Glucagon & Increased \\
\hline aTriglyceride-free fatty acid-very low density lipoprotein-triglyceride cycle.
\end{tabular}

pheochromocytoma (catecholamines), glucagonoma, thyrotocicosis (thyroxine, triiodothyronine), and insulinoma (IR as a consequence of insulin receptor desensitization) [5]. Since these diseases were accompanied by IR, the respective hormones became the focus of IR research (called the insulin antagonists; not to speak of antibodies to insulin or insulin receptor). However, in the diseases mentioned in Table 1, IR was not accompanied by enormous serum levels of hormones as in these endocrine tumors.

Physiological conditions and disease states with upregulated stress hormones were found to be accompanied by IR, such as in psychological stress, psychiatric disease, starvation, fasting, and others (Table 1). The activation of stress axes is very closely related to the abovementioned cluster of mental activation. For example, an overactive stress system has been described in different forms of IR $[26,27]$. Stress system activation is an explanatory model for IR, still in vogue [28-33], but in 1993 the mainstream of research turned to inflammation-related IR (discussed in the paragraphs following the next paragraph) [34].

In addition, several authors indicated the central role of the brain because it dictates nutrient intake and foraging behavior. Excess energy intake per se would be an important factor for obesity and, thus, a possible cause of subsequently developing IR. This has been demonstrated in humans to play a role in congenital severe obesity with congenital leptin deficiency [35], or a mutation in the melanocortin receptor type 4 [36]. There is a highly delicate system of hypothalamic regulation of satiety 
Table 3. Methods to measure insulin resistance

\begin{tabular}{|c|c|c|}
\hline Technique & Notes & Reference \\
\hline \multicolumn{3}{|l|}{ Reference methods } \\
\hline Hyperinsulinemic euglycemic clamp & Gold standard, highly invasive & [114] \\
\hline Frequently sampled intravenous glucose tolerance test & Silver standard, invasive & [132] \\
\hline \multicolumn{3}{|l|}{ Oral glucose tolerance test } \\
\hline Insulin sensitivity glycemic index $=1+2 /(I N S p \times$ GLYp) & Most commonly used, little invasive & [133] \\
\hline Whole body insulin sensitivity & Little invasive & [133] \\
\hline Muscle IS = ( $\Delta$ glucose $/ \Delta$ time $) /$ mean plasma insulin ${ }^{a}$ & Little invasive & [134] \\
\hline Hepatic IS $=$ glucose $_{0-30 \text { minutes }}[\mathrm{AUC}] \times$ insulin $_{0-30 \text { minutes }}[\mathrm{AUC}]^{\mathrm{b}}$ & Little invasive & [134] \\
\hline \multicolumn{3}{|l|}{ Fasting simple indices } \\
\hline Homeostasis model assessment insulin resistance (HOMA-IR) & Non-invasive & [133] \\
\hline Newer version of the HOMA-IR (HOMA2-S) & Non-invasive & [133] \\
\hline $\mathrm{FGIR}=$ fasting glucose $(\mathrm{mg} / \mathrm{dl}) /$ fasting insulin $(\mathrm{mU} / \mathrm{l})$ & Non-invasive & [133] \\
\hline Quicki = $1 /($ log fasting insulin $(\mathrm{mU} / \mathrm{l})+$ log fasting glucose $(\mathrm{mg} / \mathrm{dl}))$ & Non-invasive & [133] \\
\hline \multicolumn{3}{|l|}{ Biochemical markers of insulin resistance } \\
\hline Sex hormone binding globulin & Non-invasive & [133] \\
\hline Insulin-like growth factor binding protein 1 & Non-invasive & [133] \\
\hline $\begin{array}{l}\text { Other markers: YKL-40, alpha-hydroxybutyrate, soluble CD36, leptin, } \\
\text { resistin, interleukin-18, retinol binding protein-4, and chemerin }\end{array}$ & Non-invasive & [135] \\
\hline
\end{tabular}

AUC, area under the curve; GLYp, area under glucose curve; INSp, area under the insulin curve; IS, insulin sensitivity. ${ }^{\mathrm{a} T h e}$ rate of decay of plasma glucose concentration

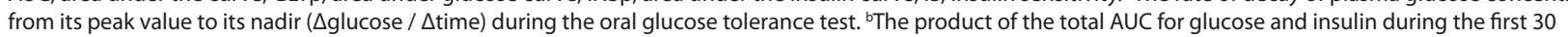
minutes of the oral glucose tolerance test.

versus food intake, which is influenced by distinct pathways within the brain and from the periphery [31,37]. Close relationships exist with psychological components comprising mood disturbances, altered reward perception and motivation, or addictive behavior [38]. The interested reader is referred to comprehensive reviews of the subject $[31,38,39]$.

Nowadays, inflammation-mediated IR is another important explanatory platform of IR in adipocytes, myocytes, and hepatocytes $[7,34,40,41]$. Disruption of insulin signaling at the level of insulin receptor substrate- 1 and insulin receptor substrate- 2 and further downstream by tumor necrosis factor (TNF) signaling, toll-like receptor signaling, nuclear factor- $\mathrm{k} B$ and inhibitor of nuclear factor- $\mathrm{kB}$, and FoxO1 activation are key elements of inflammation-related IR $[6,40,42]$. Crucial cytokines in IR are TNF, interleukin (IL)-1ß, IL-6, IL-18, and adipokines. Although the concept behind inflammationrelated IR is convincing, neutralization of TNF or IL-1 $\beta$ had no influence on IR in obese patients or T2D patients [40]. This might depend on the redundancy of cytokine pathways because, typically, only one cytokine is neutralized while many cytokines act in parallel. This might be overcome by a broader inhibition of proinflammatory signaling pathways, which has been shown for salsalate therapy that reduced IR in patients with T2D [43]. In patients with CIDs, TNF and IL-6 neutralizing strategies reduced IR $[20,44,45]$. Until now it is not clear why the neutralizing strategies perfectly improve insulin sensitivity in CIDs but not in patients without CIDs. This discrepancy will be discussed in a model of IR that integrates the findings of CID patients (see below).

In addition to the cytokine-centered theory of IR, a relatively new aspect is nutrient-induced inflammation that leads to endoplasmic reticulum stress, activation of jun-N-terminal kinase, and inhibition of insulin receptor substrate- 1 and AKT (v-akt murine thymoma viral oncogene homolog 1) and, thus, IR in the liver and adipose tissue [6]. In this model of metaflammation (metabolic inflammation), free fatty acids can activate toll-like receptors, and free fatty acids and glucose undergoing oxidation in mitochondria stimulate free radical production, both of which inhibit insulin signaling $[6,46]$. The theory describes that nutrient overload in our modern society of affluence gradually increases the involvement of immune system pathways. This leads to ongoing inflammation, mainly in fat tissue as substantiated by leukocyte infiltration (the macrophage is the big player). In consequence, involvement of these inflammatory pathways intensifies the inhibition of metabolic pathways [6]. In addition, in patients with obesity, changes of the gut microbiota were observed, which in itself can be an inflammatory factor that contributes to IR [47-49]. 
In this short pathophysiology collection of IR, we recognize again the two clusters linked to IR: inflammation with an activated immune/repair system; and increased mental activation (mood, food intake, stress and stress axes). However, the appearance of the two clusters is not yet explained by the interplay of the abovementioned pathophysiological elements. Possibly, published theories on IR with an evolutionary perspective might help to explain the two clusters.

\section{Evolutionary medicine - theories of insulin resistance, 1962 to 2014}

The theories of IR are summarized in Table 4 and are shortly recapitulated here. The thrifty genotype hypothesis of 1962 states that a gene has been positively selected for an exceptionally efficient intake and utilization of food, which was good for hunter-gatherers in a feast/ famine environment but is not good for modern people in a world of plenty. In the original theory, a single gene was made responsible for rapid postprandial insulin release that supported quick storage of energy-rich substrates (called the quick insulin trigger) [50,51]. While the original theory focused on the quick insulin trigger, an alternative model focused on possible genes involved in IR [52]. Today, we know that obesity and IR are based on a polygenic background with many single nucleotide polymorphisms with small effect sizes. Selection on such mutations would probably be very weak because the individual advantages they would confer would be very small. The theory has been criticized due to modest support by genetic analyses; it has been even rejected, but it is still in use and has been adapted by researchers in the field of eating disorders [53].

Another theory of starvation-induced IR proposes that IR of the muscle during fasting is a positively selected program to maintain high circulating glucose levels in order to protect muscle from proteolysis during starvation [52,54]. In addition, during starvation, lipolysis is switched on, leading to provision of free fatty acids and then ketone bodies that can be used by the brain. Both mechanisms spare glucose and glucogenic amino acids in the muscle. IR in the context of starvation is of a special form because insulin levels are very low, no inflammation accompanies starvation, and counterregulatory hormones such as glucagon and cortisol are continuously upregulated. This situation does not apply to IR observed in CIDs and obesity because hyperinsulinemia and inflammation are a hallmark.

Another important theory of IR is the thrifty phenotype hypothesis $[55,56]$. This model is based on the important observations that underweight babies more often develop IR and obesity compared with normal weight children. In this theory, intrauterine malnutrition and other fetal constraints induce insulin deficiency (lack of the growth-promoting activities of insulin) and a postnatal state of regulatory IR, which leads to rapid postnatal increase of adipose tissue that remains stable throughout life (accompanied by cardiovascular disease in the older person, and so forth) [57]. In many studies all over the world, the epidemiological findings were very supportive of the model [55]. The theory proposes that environmental factors are the dominant cause of obesity, and that epigenetic intrauterine programming plays the critical role $[58,59]$. This theory has been refined in the predictive adaptive response model. In this supplement to the original theory, the relative difference in nutrition between prenatal and postnatal environment, rather than an absolute level of nutrition, determines the risk of IR [60]. Both thrifty phenotype theories are accepted in IR research because they have been confirmed in many studies in humans and animals. These days, it is amazing that a nongenetic theory has received so much support and attention.

Based on the thrifty genotype hypothesis, IR and immune activation were recognized as an adaptive positively selected program to combat infections (the fight infections theory of IR). The activation of the immune system during infectious disease and inflammation induces IR, which leads to redirection of glucose to the activated immune system [61]. In a modern form, this was integrated into the concept of immune cell activation by pathogen-sensing and nutrient-sensing pathways (with cytokines, toll-like receptors, jun-Nterminal kinase, and so forth) [62]. Here, even nutrients can induce an inflammatory state that can support IR, which is probably a dilemma after exaggerated food intake when nutrients cannot be adequately stored in fat tissue and elsewhere (nutrient overflow problem).

Similarly based on the thrifty genotype theory is the breakdown of robustness theory, which states that a robust glucose control system developed during evolution. The breakdown of this robust glucose control system induces positive disease-stabilizing feedback loops leading to IR. The critical determinant of the breakdown is TNF [63]. This theory incorporates many accepted aspects but TNF is not the sole pathophysiological factor.

With the discovery of leptin, a negative feedback loop between adipose tissue and food intake was discovered. While in earlier times many argued that energy homeostasis operates primarily to defend against weight loss, the discovery of the leptin negative feedback loop speaks for homeostatic mechanisms that inhibit uncontrolled weight gain. The central resistance model states that central hypothalamic pathways are defective (resistant to leptin and others such as insulin). This leads to increased food intake and the resulting obesity induces IR [64]. This theory has much value because it added the 
Table 4. Characteristics of theories on insulin resistance as observed from an evolutionary medicine standpoint

\begin{tabular}{|c|c|c|}
\hline Theory of insulin resistance & Year & Reference \\
\hline $\begin{array}{l}\text { Thrifty genotype hypothesis: quick hyperinsulinemia after food intake to store energy in fat tissue and elsewhere } \\
\text { (quick insulin trigger) }\end{array}$ & 1962, 1999 & {$[50,51]$} \\
\hline $\begin{array}{l}\text { (Not so) Thrifty genotype hypothesis: starvation induces a special form of IR in order to conserve nitrogen } \\
(=\text { amino acids from muscle and elsewhere) }\end{array}$ & 1979 & [54] \\
\hline $\begin{array}{l}\text { Thrifty phenotype hypothesis: intrauterine constraints induces IR and insulin deficiency, which allows the organism to survive } \\
\text { long enough to reproduce in a nutritionally deprived environment but which leads to obesity in a world of plenty; maternal } \\
\text { constraints support IR (small mother, first baby, many babies in parallel, maternal undernutrition, and similar) }\end{array}$ & 1992, 2001 & {$[55,56]$} \\
\hline $\begin{array}{l}\text { Based on the thrifty genotype hypothesis: an insulin resistance genotype and a cytokine genotype exist (much IR, high } \\
\text { cytokine response); IR is helpful for infections }\end{array}$ & 1999 & [61] \\
\hline $\begin{array}{l}\text { Refined thrifty phenotype theory: predictive adaptive response model: the relative difference in nutrition between the prenatal } \\
\text { and postnatal environment, rather than an absolute level of nutrition, determines the risk of IR }\end{array}$ & 2004 & {$[60]$} \\
\hline $\begin{array}{l}\text { Central resistance model: there exists a homeostatic regulation of weight gain versus weight loss but defects in the weight } \\
\text { loss system leads to obesity (for example, insulin and leptin signaling, SOCS3, PTB-1B) }\end{array}$ & 2004 & [64] \\
\hline $\begin{array}{l}\text { Thrifty genotype plus breakdown of robustness: the basis is the thrifty genotype model; a robust glucose control system } \\
\text { evolved during evolution, the breakdown of which induces positive disease-stabilizing feedback loops (TNF) }\end{array}$ & 2004 & [63] \\
\hline Thrifty genotype: integration of cellular pathogen-sensing and nutrient-sensing pathways (cytokines, TLRs, JNK, Ikk $\beta$, PKC, ER stress) & 2006 & [62] \\
\hline $\begin{array}{l}\text { Good calories-bad calories hypothesis: wrong nutrients, particularly carbohydrates, lead to obesity and IR; a paleolithic diet } \\
\text { has quite different qualities that prevents obesity and western diseases }\end{array}$ & 2010,2012 & {$[65,66]$} \\
\hline
\end{tabular}

ER, endoplasmic reticulum; Ikk $\beta$, inhibitor of nuclear factor-KB kinase $\beta ;$ IR, insulin resistance; JNK, jun-N-terminal kinase; PKC, protein kinase C; PTB-1B, protein tyrosine phosphatase $1 \mathrm{~B} ; \mathrm{SOCS3}$, suppressor of cytokine signaling 3; TLR, toll-like receptor; TNF, tumor necrosis factor. ${ }^{2}$ This is a special form of IR without hyperinsulinemia on the basis of a strong response of counterregulatory hormones. It is questionable to call it IR because of missing hyperinsulinemia and missing inflammation. In addition, activity of the sympathetic nervous system is low while activity of the hypothalamic-pituitary-adrenal axis is high in the typical nadir.

central regulation of food intake to the peripheral pathophysiologic pathways.

Finally, the good calories-bad calories theory explains that our present food is markedly different from paleolithic food. Particularly, high energy-dense carbohydrates are consumed too often, which induces inadequate hyperinsulinemia [65]. Long-term hyperinsulinemia is the platform for obesity and disease sequelae. Others hypothesized that disparities between paleolithic and contemporary food might be important factors underlying the etiology of common western diseases [66]. Typically the type of ingested lipids and the relative amount of carbohydrates/lipids versus proteins is a problem.

In conclusion, the theories already indicate that IR can be an important aspect to support the brain and the activated immune system. As such, IR can be seen as a positively selected program to support the brain or immune system. In the following sections, this concept is further developed by including aspects of energy regulation.

\section{Energetic benefits of insulin resistance for non-insulin-dependent tissue}

At this point, I recapitulate that IR increases circulating glucose and free fatty acids that are not taken up in adipose tissue, liver, and muscle, and are now freely available to all non-insulin-dependent tissues. The two main profiteers of hyperglycemia are the central nervous system and the immune system because either glucose, free fatty acids (not the brain), or ketone bodies are energetic substrates. Both of these organs do not become insulin resistant. In contrast, the immune system profits from insulin because it is an important growth factor for leukocytes and, with the help of insulin, major glucose transporters like glucose transporter-3 and glucose transporter-4 are upregulated on all leukocyte subpopulations [67]. In answering the question of whether, for example, hepatic glucose production really provides higher levels of circulating energy, the following simple calculations are presented for glucose (similar calculations can be done for free fatty acids).

One important factor of IR is overproduction of hepatic glucose [68]. In normal subjects, hepatic glucose production after an overnight fast is approximately $2.0 \mathrm{mg} / \mathrm{kg}$ per minute. Under a situation involving IR, for example in T2D patients, insulin is 2.5 -fold increased and the rate of fasting glucose production can increase to $2.5 \mathrm{mg} / \mathrm{kg} /$ minute [68]. After an overnight fast during an observation period of 12 hours, the liver of a normal person of $80 \mathrm{~kg}$ bodyweight produces $115 \mathrm{~g}$ glucose. Using the above given numbers, a person with IR produces $144 \mathrm{~g}$ glucose, leading to an increase of $29 \mathrm{~g}$ in 12 hours. An increase of $2 \times 29 \mathrm{~g}=58 \mathrm{~g}$ glucose in 24 hours corresponds to $974 \mathrm{~kJ}$ in 24 hours, which is a pretty high number in the light of the normal metabolic rate of $10,000 \mathrm{~kJ} /$ day of an $80 \mathrm{~kg}$ person (sedentary way of life). Indeed, $974 \mathrm{~kJ}$ represents approximately $39 \%$ of the total energy need of the normally active central nervous system, or it represents $61 \%$ of the energy requirements of all resting immune cells (Table 5). IR is thus a perfect 
Table 5. Energy expenditure of systems and organs under sedentary conditions (approximately 10,000 kJ/day)a $[69,70,136-139]$

\begin{tabular}{|c|c|}
\hline System/organ & $\begin{array}{l}\text { Energy expenditure } \\
\text { per day ( } \mathrm{k} / \text { day) }\end{array}$ \\
\hline Muscle at rest ${ }^{\mathrm{b}}$ & 2,500 \\
\hline Central nervous system (brain and spinal cord) & 2,500 \\
\hline Immune system in a quiescent state ${ }^{c}$ & 1.600 \\
\hline 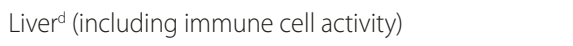 & 1,600 \\
\hline Heart $^{b}$ & 1,200 \\
\hline $\begin{array}{l}\text { Gastrointestinal tract (including gut immune system, } \\
\text { without liver, kidney, spleen)d }^{d}\end{array}$ & 620 \\
\hline Kidneys & 600 \\
\hline Spleen (erythrocytes plus leukocytes; $90 \%$ anaerobic) & 480 \\
\hline Lungs (including lung immune system) & 400 \\
\hline Skin (including skin immune system) & 100 \\
\hline
\end{tabular}

${ }^{\mathrm{a}} 10,000 \mathrm{~kJ}=2,388 \mathrm{kcal}$. ${ }^{\mathrm{b}} \mathrm{Activ}$ ated muscle has a much higher metabolic rate: for example, a Tour de France bicyclist needs approximately $30,000 \mathrm{~kJ} /$ day, which is $20,000 \mathrm{~kJ}$ more than under sedentary conditions. The 20,000 kJ are used predominantly by the muscles and also the heart. At the upper limit of gastrointestinal resorption, the total body daily uptake (absorptive capacity in the gut) is $20,000 \mathrm{~kJ} /$ day. cModerate activation of the immune system increases daily energy needs to approximately $2,100 \mathrm{~kJ} /$ day, and strong activation increases the daily need to 3,000 kJ/day. ${ }^{\mathrm{d} E n e r g y}$ need is difficult to estimate independent of the immune system in some organs.

way to support the activity of the central nervous system, the immune system, and/or other insulin-independent tissues (for example, the heart; Table 5).

In conclusion, while IR is most often regarded as a pathological state to be treated, these numbers and the fact that IR is linked to so many diseases and disease states are indicative of a beneficial role of IR. While the value of IR can be estimated from the abovementioned numbers, the generation of the two disease clusters is not yet clear.

\section{The selfish brain and the selfish immune system independently demand energy}

This section demonstrates aspects of hypothetical character, and the reader is advised to critically judge the theoretical model. The basal metabolic rate of the entire body is determined when the following conditions are met [69]: awake, lying, after overnight fast, thermoneutral (no heat production due to low/high temperature), and no emotional stress [69]. Under these conditions, a person weighing $80 \mathrm{~kg}$ and $1.80 \mathrm{~m}$ in height needs approximately 10,000 kJ/day (Table 5).

The so-called minimal metabolic rate is lower than the basal metabolic rate because $15 \%$ of energy is spared during sleep, so that a 24-hour sleeping person weighing $80 \mathrm{~kg}$ and $1.80 \mathrm{~m}$ in height needs $8,500 \mathrm{~kJ} /$ day. This amount of energy is not up for negotiation between the different organs. The delta value between this last number and the maximum of daily energy uptake in the gut $(20,000 \mathrm{~kJ} /$ day; see Table 5$)$ is $11,500 \mathrm{~kJ} /$ day. In this example, $11,500 \mathrm{~kJ} /$ day is the controllable amount of energy (CAEN) because allocation of the CAEN to different organs is controlled by the interplay of these organs. This amount of energy is available for negotiation. The question is which organs are dominant in regulating the CAEN. Dominance can be judged when looking at Table 5, which shows the main users of energy, but can also be derived from simple theoretical considerations.

For example, if a paleolithic hunter experiences tissue trauma with infection, the immune/repair system becomes strongly activated. In this life-threatening situation, regulation of CAEN allocation to the immune/ repair system must be independent of other organs and immediate (hierarchically, the highest level of control to survive). In this situation, circulating cytokines and activated sensory nerve fibers are responsible for the immediate reallocation of the CAEN to the activated immune system that increases energy consumption (Table 5) [70]. This reaction is called the energy appeal reaction [70].

Similarly, if the brain is active during hard forest work over 6 hours, for example, then the skeletal muscles, heart, lungs/diaphragm, and liver are also active, but most other organs are at minimal metabolic levels. This is particularly true for the gastrointestinal tract and the immune system. In this example of 6-hour forest work, a person weighing $80 \mathrm{~kg}$ and $1.80 \mathrm{~m}$ in height would need $18,500 \mathrm{~kJ}$ for the entire day (calculated using data from [71]). The brain controls the additional CAEN of $10,000 \mathrm{~kJ}$ when there is need for forest work. Likewise, if a paleolithic hunter needs to escape from a severe dangerous threat, the brain must control the CAEN. In such a life-threatening situation, the control of the CAEN by the brain must be independent of other organs (again, the highest level of control to survive).

With trauma/infection or fight/flight response, the activity of most organs depends on either the immune/ repair system or the central nervous system, respectively. We recently delineated that allocation of CAEN to the brain and muscles happens mainly during daytime, while allocation of CAEN to the immune/repair systems happens at night [70]. This circadian allocation of energyrich substrates is another clear indication of tight energy regulation. From these theoretical considerations, it becomes clear that either the immune/repair system or the central nervous system is a dominant regulator of the CAEN.

Coming back to the Introduction, with this model the two clusters of clinical entities linked to IR become understandable in terms of energy regulation. One recognizes two independent organs - the selfish immune system, and the selfish brain $[37,72]$ - related to the abovementioned clusters of inflammation with an 
activated immune/repair system and of increased mental activation.

With the chronic inflammatory and chronic mental diseases that induce IR (listed in Table 1), the question arises of whether or not brain-supporting and immune system-supporting IR has been positively selected for acute disease or chronic disease. Such a distinction is not included in the available theories of IR, but it might be helpful to understand the role of IR in general.

\section{A difference between acute and chronic disease}

While an acute response is often adaptive and physiological to correct alterations of homeostasis, a chronic disease process is often accompanied by the wrong program [70,73]. Looking at simple readout parameters, this can be demonstrated for immune/repair system activation and mental activation.

The acute activation of the immune/repair system is outstandingly important to fight acute infections and trauma. However, longstanding inflammation in CIDs leads to severe disease sequelae as summarized recently $[70,73]$. The following disease sequelae are directly linked to CIDs: sickness behavior, anorexia, malnutrition, muscle wasting-cachexia, cachectic obesity, IR with hyperinsulinemia, dyslipidemia, increase of adipose tissue near inflamed tissue, alterations of steroid hormone axes, elevated sympathetic tone and local sympathetic nerve fiber loss, decreased parasympathetic tone, hypertension, inflammation-related anemia, and osteopenia [70,73]. It was suggested that these sequelae of CIDs are a consequence of a high energy demand of the activated immune/repair system accompanied by water retention $[70,73]$. Acute activation of the immune/ repair system can be very helpful, but chronic activation is a harmful process that worsens the situation in an affected patient.

Considering mental activation, we can also separate acute versus chronic. In the acute situation of emergency for a loved one, family members and hospital staff show strong mental activation that can lead to a higher state of activity, a better readiness to take action, but also poor sleep and symptoms of anxiety [74,75]. Similarly, student's examination stress can lead to a higher state of activity but also to poor sleep and acute increase in anxiety scores [76,77]. Acute examination stress increased intake of highly palatable food in an unproportional manner [78]. In these acute situations, mental activation, poor sleep, and increase in food intake are important to overcome the challenging situation.

However, long-term caregivers of, for example, Alzheimer disease patients are more often obese than noncaregivers, demonstrate alterations typical of the metabolic syndrome, show a higher risk to develop major depression, and have a long-term increase in proinflammatory markers [79-84]. Similarly, chronically stressed students in a highly competitive university environment showed an increased risk of obesity [14]. A dose-response relationship was found between chronic work stress and risk of general and central obesity that was largely independent of covariates such as age, sex, and social position [11], supported in other large studies $[12,13]$. Moreover, chronic job stress was related to an increased risk of the metabolic syndrome and even T2D [85-87]. Chronically poor sleep is related to metabolic risk factors, obesity, and inflammation [88].

This small collection demonstrates that activation of the immune/repair and central nervous systems are successful in acute emergency, but dangerous when applied chronically, leading to typical signs of obesity, metabolic derangement with IR, chronic inflammation, and increased risk for cardiovascular events [89]. The question is why there is such a clear distinction between acute and chronic, which determines the full picture of the metabolic syndrome and IR.

\section{Evolutionary medicine - acute physiological response versus chronic disease}

Earlier, it was demonstrated that a highly activated immune/repair system cannot be switched on for a long time because this would be very energy consuming [73]. A highly activated immune system is accompanied by sickness behavior and anorexia, which prevents adequate food intake and necessitates life on stored reserves (inflammation-induced anorexia). Under systemic inflammatory conditions, breaking down all reserves takes 19 to 43 days [73]. A highly activated immune/repair system can need huge amounts of energy, which is exemplified in the case of extensive burn wounds (up to $20,000 \mathrm{~kJ} /$ day) [73]. Although this aspect demonstrates the extreme of the spectrum, it indicates that energy consumption is a critical factor during evolution.

I hypothesize that energy consumption and energy protection are the most critical determinants in evolution, to undergo either negative selection or positive selection, respectively. If alterations of homeostasis lead to marked energy consumption, the situation cannot be chronic - it must be acute. Since the total consumption time ranges between 19 and 43 days [73], an acute energy-consuming change of homeostasis must be started and terminated in this time frame. A very good example for this time window is the germinal center reaction of B-lymphocyte expansion and contraction that happens within approximately 21 to 28 days [90]. Most acute disease states are terminated within this time frame, such as infectious diseases, wound healing, and repair, but also strong mental activation in stressful situations must be terminated because they are energy consuming, exemplified in short-term stress [78]. During 
evolution, respective homeostatic networks were positively selected for short-lived, acute, energyconsuming responses but not for longstanding polygenic CIDs or chronic mental illness. These chronic situations generated a huge negative selection pressure.

In contrast, if mutations were helpful to protect energy reserves, they were positively selected during evolution. This is true for memory responses because immediate reaction of an educated system can spare energy reserves. This is exemplified by the immune memory that leads to shorter, more effective and, finally, less energy-consuming reactions towards microbes. Importantly, acquisition of immune memory during the primary contact must fit into the above specified time frame of 19 to 43 days (and this happens as exemplified by the germinal center reaction in secondary lymphoid organs). In this context, tolerance versus harmless foreign antigens of microbes on body surfaces (see gut, skin, respiratory tract, urogenital tract) or harmless autoantigens is a memory function that spares energy reserves. Sometimes microbes such as Mycobacterium tuberculosis, Mycobacterium leprae, and viruses enable or mimic tolerant immune responses leading to longstanding infection, but finally leading to death due to emaciation.

Similarly, neuronal memory can largely decrease time to accomplish successful foraging in the wild [91]. Neuronal memory systems are tuned to ancestral priorities in the context of foraging and other paleolithic tasks [92]. Additionally, tool-making, invention of language and writing, and storage of data on computer hard disks protects time and thus energy.

Another example of positively selected gene variants is observed for food ingestion and fat storage (not IR!), both of which are important in determining the abovementioned consumption time. Indeed, female Australopithecus afarensis had a consumption time of approximately 19 days, while modern female Homo sapiens can rely on 43 days [73]. Particularly, fat storage has markedly increased over the last 3 to 4 million years of human evolution. Not surprisingly, the latest metaanalysis of genome-wide association studies of obesity and the metabolic syndrome (not IR) found polymorphisms in genes relevant for food intake such as FTO (fat mass and obesity related), $M C 4 R$ (melanocortin receptor type 4), $P O M C$ (proopiomelanocortin, the precursor of melanocortin), and genes relevant for fat storage such as the insulin-stimulating GIPR (gastric inhibitory polypeptide receptor) [93].

Another important indication for positive selection of fat storage networks (not IR) is given by the fact that the number of adipocytes in humans is determined before puberty [57]. After puberty, the number of adipocytes stays constant with an annual exchange rate of $10 \%$ [57]. If spontaneous mutations lead to a phenomenon relevant before reproduction time, it will be easily transferred to offspring when it is an advantageous trait. Since the phenomenon still exists in modern children [57], we expect that fat storage was an important factor during evolution. Similarly, humans can deposit large amounts of fat in utero and are consequently one of the fattest species at birth [94]. In addition, newborn humans devote roughly $70 \%$ of growth expenditure to fat deposition during early postnatal months, which reduces the risk of energy stress during infections [94]. If the newborns are not able to store large amounts of fat tissue in utero, or if malnutrition is a problem in fetal life (thrifty phenotype model, see above; Table 4), a postnatal program seems to be switched on that supports obesity during childhood and adolescence [55,56]. Again this is an indication that important positively selected gene variants exist that serve storage of energy.

In conclusion, networks are positively selected if they serve acute, highly energy-consuming situations, which are terminated within 3 to 6 weeks. We perceive a chronic disease when it lasts for longer than 6 weeks, as used in classification criteria in RA and juvenile idiopathic arthritis [95]. In addition, gene variants are positively selected if they protect energy stores, which is relevant during the entire life (beyond weeks 3 to 6). Networks that lead to IR serve the acute activation of the selfish immune system or the selfish brain, but do not belong to networks that protect energy stores (Figure 1). In contrast, IR leads to loss of energy-rich substrates because it is a catabolic process (energy-rich fuels are consumed by non-insulin-dependent organs or are simply excreted) (Figure 1). If the hypothesis of the acute IR program is correct, then chronic IR in chronic inflammation, in CIDs, and in chronic mental activation or mental disease is a misguided acute program. In contrast to IR, food intake and storage of energy-rich substrates in adipose tissue per se is not a misguided program. In other words, obesity is not dangerous and obesity is not a disease [96]. Yet obesity becomes a problem if additional factors are switched on that usually serve acute energy-consuming situations (mental activation or inflammation). Per Björntorp once noticed that 'some disease-generating factors, in addition to the basic condition of central obesity, is required for associated diseases to become manifest' [96].

\section{The new model of insulin resistance}

With all this information, one can generate a new model of IR that builds upon the existing theories. The new model includes four new aspects: it respects much more the immune/repair system, whose energy requirements are enormous (Table 5) [70]; it juxtaposes the selfish brain and the selfish immune system on a similar hierarchical level in terms of energy demand and 
requirements (Table 5); it respects that energy requirements convey an evolutionary pressure (highly energyconsuming states are acute (negative selection pressure), energy storage is beneficial (positive selection pressure)); and it accepts that either immune system activation or mental activation are equally important in inducing IR. On the basis of these elements, a new model of IR is presented in Figure 1. This model states that IR is an acute catabolic program to serve the selfish immune system or the selfish brain, positively selected for inflammation with an activated immune/repair system and for increased mental activation.

Several testable hypotheses can be generated from the new model, as follows. Obesity is only a problem if acute energy-consuming programs are switched on (either inflammation or mental activation cause the problem). Immunological tolerance should support the storage function of fat tissue and muscle. Nutrient-induced inflammation is only a problem if energy-rich fuels are not properly stored (there is an individual storage threshold). Intrauterine constraints (elements of the thrifty phenotype model) should set the thresholds for acute activation programs. While there is a clear link between fat tissue and brain (leptin), there should be similar pathways between the liver/brain and the muscle/ brain that regulate food intake - concerning the muscle/ brain pair, a recent paper found important links through muscle-derived IL-6 [97]. In CIDs, the selfishness of the immune system should lead to an inhibition of braindependent regulation of energy allocation. Likewise, in mental illness or chronic psychological stress, the selfishness of the brain should lead to inhibition of the immune system-dependent regulation of energy allocation. In CIDs and mental illness/stress, the two systems must inhibit each other.

\section{The drivers of insulin resistance in chronic inflammatory and mental diseases}

A seminal study demonstrated the interrelation between the dose of subcutaneously injected recombinant human IL-6, serum levels of IL-6, and the increase of energy expenditure in healthy volunteers [98]. Injection of $0.1 \mu \mathrm{g}$ recombinant human IL-6/kg bodyweight increased serum levels of IL-6 to approximately 10 to $15 \mathrm{pg} / \mathrm{ml}$, $1.0 \mu \mathrm{g}$ led to $45 \mathrm{pg} / \mathrm{ml}, 3.0 \mu \mathrm{g}$ stimulated a serum level of $250 \mathrm{pg} / \mathrm{ml}$, and $10 \mu \mathrm{g}$ recombinant human IL-6/kg bodyweight was accompanied by an IL- 6 serum concentration of more than $1,000 \mathrm{pg} / \mathrm{ml}$. In parallel, the maximal increase of metabolic rate in percent of basal metabolic rate was $4 \%, 7.5 \%, 18 \%$, and $25 \%$, respectively [98]. This means that a visible influence on energy regulation was observed at a serum level of 10 to $15 \mathrm{pg} / \mathrm{ml}$, but the effect was small in these healthy volunteers. In contrast, serum levels of $45 \mathrm{pg} / \mathrm{ml}$ were related to an increase in metabolic rate of $7.5 \%$, which would amount to approximately $750 \mathrm{~kJ} /$ day in a normal-sized healthy subject (basal metabolic rate: 10,000 kJ/day). An increase of serum IL-6 from 1 to $2 \mathrm{pg} / \mathrm{ml}$, as in healthy subjects [99], to $45 \mathrm{pg} / \mathrm{ml}$ thus induces a marked energy expenditure program.

Under consideration of the new model in Figure 1, we immediately recognize the problem of continuous inflammation in CIDs. CIDs such as RA are accompanied by markedly elevated serum levels of IL- 6 ranging from $40.0 \mathrm{pg} / \mathrm{ml}$ before anti-TNF therapy to $8.0 \mathrm{pg} / \mathrm{ml}$ after anti-TNF therapy [100]. The levels are thus much higher as compared with healthy subjects ( 1 to $2 \mathrm{pg} / \mathrm{ml}$ [99]). Untreated patients with RA should increase daily energy expenditure by $750 \mathrm{~kJ} /$ day (basal metabolic rate: $10,000 \mathrm{~kJ} /$ day). This value of $750 \mathrm{~kJ} /$ day is remarkably similar to the number of $974 \mathrm{~kJ} /$ day obtained by hepatic IR as calculated above. Since we expect that several cytokines like TNF, IL-6, interferon gamma, interferon alpha, and others can drive a similar energy reallocation program, elevation of systemic cytokines explains why patients with CIDs do not need any other factor to provoke IR. These CID patients do not need the activation of the brain and thus activation of stress axes to induce IR. The brain is silenced in CIDs (sickness behavior). IR can be stimulated by a direct influence of cytokines on hepatocytes, adipocytes, and myocytes. We now understand why cytokineneutralizing therapies work perfectly well in RA - because the key IR factor is removed. When cytokine-neutralizing strategies do not work in obese or T2D people, other parallel factors must play an enormous role.

The inflammatory load is remarkably different in the situation of chronic mental illness or psychological stress where mild peripheral inflammation probably plays a small supportive role. When one compares serum levels of IL-6 as measured with the identical quantitative highsensitivity enzyme-linked immunosorbent assay technique, healthy subjects range between 1 and $2 \mathrm{pg} / \mathrm{ml}$ [99], caregivers show a mean value of $5.5 \mathrm{pg} / \mathrm{ml}$ [101], and subjects who report a high level of perceived hopelessness show $3.0 \mathrm{pg} / \mathrm{ml}$ [102]. These levels correspond to mild activation of the immune system, but they would not lead to an energy reallocation program [98]. Thus, in mental activation, stress axes must play the major role for the observed IR (cortisol, adrenaline, growth hormone, glucagon). It is expected that neutralization of one cytokine would not change IR in these mentally activated people. Furthermore, when cytokine neutralizing strategies do not work in T2D patients, several factors in parallel are expected to drive IR. It is interesting that salsalate had a positive impact on IR in T2D [43], but this type of drug and other nonsteroidal anti-inflammatory drugs can also inhibit mental activation in various chronic psychiatric diseases [103-105], which is most probably related to reduced activation of stress axes. 


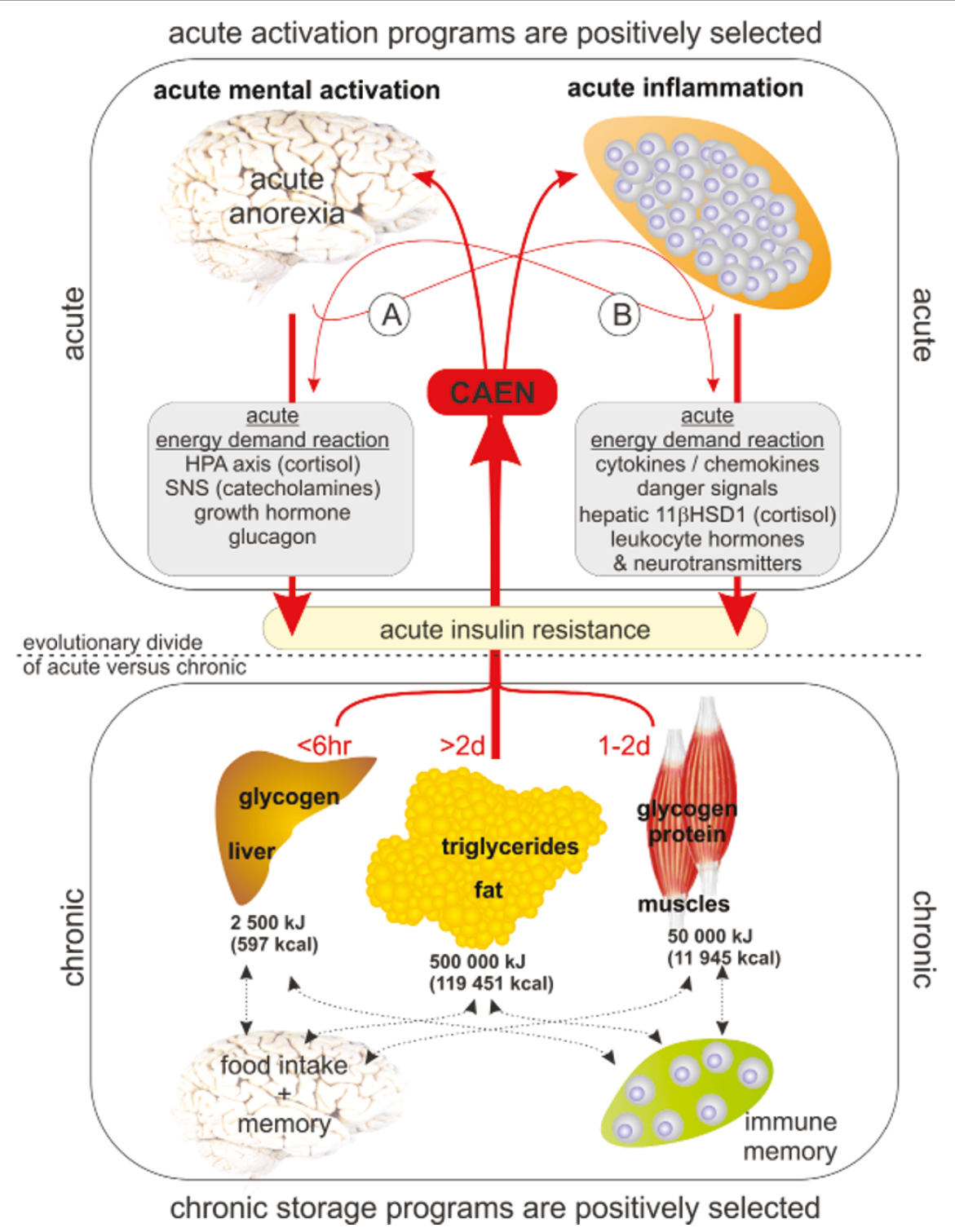

Figure 1. Pathophysiology of insulin resistance according to the new theory. Upper panel: Acute activation programs were positively selected for short-lived activation of either the brain or the immune system. Hierarchically, the brain and the immune system are on the same level. Activation of the brain mainly stimulates stress axes hormones and activates the sympathetic nervous system (SNS). This is supported by a mild inflammatory process that is paralleled by mental activation (A). Activation of the immune system induces cytokines, chemokines, and danger signals. In addition, the inflammatory process uncouples the locally inflamed area from the control of the brain by cytokine-induced hormone/ neurotransmitter production in the periphery independent of superordinate stress pathways. This leads to hepatic cortisol secretion [140], adrenocorticotropic hormone-independent cortisol secretion [141], and production of leukocyte hormones [142] and leukocyte neurotransmitters [143]. The activation of the immune system is accompanied by a mild stimulation of the hypothalamic-pituitary-adrenal axis (HPA) axis (albeit inadequately low in relation to inflammation) and a somewhat stronger stimulation of the SNS (B). Despite activation of the SNS, anti-inflammatory neurotransmitters of sympathetic nerve fibers do not reach the uncoupled inflamed tissue [144]. Inflammatory and mental activation are often accompanied by anorexia and sickness behavior, which aggravates energy shortage. Lower panel: Chronic energy storage and memory programs were positively selected. The major storage organs are fat tissue (glycerol, free fatty acids) and muscles (proteins). The liver is more a switchboard to interchange and renew energetic substrates. The main storage factor is insulin so that insulin resistance can be seen as a catabolic program induced by catabolic pathways (upper panel). Numbers in red give the typical time of energy provision by the respective organ (amino acids from muscle are spared from day 3 onwards). Storage is mainly supported by a positively selected program of foot intake/foraging behavior and memory. Memory is outstandingly important to spare energy-rich fuels (brain, immune system). Dashed black arrows in the lower panel demonstrate real and hypothetical connections between respective organs. Black numbers give a typical figure of stored energy in the respective organs. Dashed black line between upper and lower boxes separates the programs positively selected for acute (catabolic) versus chronic states (storage and memory). CAEN, controllable amount of energy (the energy that is regulated and negotiated between organs); 11ßHSD1, 11-beta-hydroxy steroid dehydrogenase type 1 [140]. 


\section{Conclusions}

IR is an unfavorable factor in CIDs because it supports the already activated immune system. IR is a direct consequence of the proinflammatory load. Thus, IR should be treated by neutralizing inflammatory cytokines or by inhibiting the immune system with diseasemodifying anti-rheumatic drugs in a more general way (like salsalate for T2D). Since IR is a very direct consequence of immune system activation, the primary goal is anti-inflammatory treatment. In CIDs, further treatment of IR beyond good inflammatory control is expected not to be needed. Since IR is a perfect diagnostic marker of an activated energy reallocation program (inflammation and mental activation), measuring IR might be a suitable biomarker to study the control of systemic inflammation in CIDs. Since several cytokines induce IR in a redundant manner, IR might be a more integral systemic diagnostic marker than Creactive protein, the erythrocyte sedimentation rate, or single cytokines.

In addition to aspects of IR in CIDs, this review demonstrates an extended theory of IR that classifies IR as a beneficial positively selected program to support activation of the immune/repair system and the brain. IR makes sense in acute alterations of homeostasis in the context of short-lived diseases but is a misguided program in long-term inflammatory and mental activation.

\section{Key messages}

- IR is a consequence of mental activation (neuroendocrine axes) or inflammation that is a consequence of selfishness of the brain or the immune system.

- IR has been positively selected during evolution for short-lived energy-consuming activation of the brain or immune system.

- Long-term IR supports mental disease and CIDs because energy-rich fuels are provided to these noninsulin-dependent tissues (continuous activation).

- IR in CIDs is treated by consequent reduction of the proinflammatory load.

- Treatment of IR in morbid obesity and T2D is more complex because both inflammatory and neuroendocrine pathways need to be targeted. The pleiotropic anti-inflammatory and central nervous effects of salsalate constitute the first positive drug therapy of IR in T2D.

\section{Abbreviations}

CAEN, controllable amount of energy; CID, chronic inflammatory disease; IL, interleukin; IR, insulin resistance; RA, rheumatoid arthritis; $T 2 D$, type 2 diabetes mellitus; TNF, tumor necrosis factor.

\section{Competing interests}

The author declares that he has no competing interests.

\section{Declaration}

This article has been published as part of Arthritis Research \& Therapy Volume 16 Suppl 2, 2014: At the interface between immunology and endocrinology in rheumatic diseases. The full contents of the supplement are available at http://arthritis-research.com/supplements/16/s2.

This supplement was proposed, developed and commissioned by Arthritis Research \& Therapy and was funded by an educational grant from Horizon Pharma Inc. All published articles were independently prepared by the authors and have undergone peer review in accordance with the journal's standard policies and processes. Horizon Pharma Inc had no input into the topics covered or the articles themselves. The Supplement Editor was appointed by the journal and declares that they have no competing interests.

Published: 13 November 2014

\section{References}

1. Joslin EP: The treatment of diabetes mellitus. Can Med Assoc J 1916, 6:673-684.

2. Pemberton R, Foster GL: Studies on arthritis in the army based on four hundred cases (iii). studies on the nitrogen, urea, carbon dioxid combining power, calcium, total fat and cholesterol of the fasting blood, renal function, blood sugar and sugar tolerance. Arch Int Med 1920, 25:243-282.

3. Rabinowitch IM: The influence of infection upon the reaction of the diabetic to insulin treatment. Can Med Assoc J 1924, 14:481-482.

4. Root HF: Insulin resistance and bronze diabetes. N Engl J Med 1929, 201:201-206.

5. Moller DE, Flier JS: Insulin resistance - mechanisms, syndromes, and implications. N Engl J Med 1991, 325:938-948.

6. Gregor MF, Hotamisligil GS: Inflammatory mechanisms in obesity. Annu Rev Immunol 2011, 29:415-445.

7. Hotamisligil GS, Erbay E: Nutrient sensing and inflammation in metabolic diseases. Nat Rev Immunol 2008, 8:923-934.

8. Schenk S, Saberi M, Olefsky JM: Insulin sensitivity: modulation by nutrients and inflammation. J Clin Invest 2008, 118:2992-3002.

9. Goldfine AB, Fonseca V, Shoelson SE: Therapeutic approaches to target inflammation in type 2 diabetes. Clin Chem 2011, 57:162-167.

10. Dallman MF: Stress-induced obesity and the emotional nervous system. Trends Endocrinol Metab 2010, 21:159-165.

11. Brunner EJ, Chandola T, Marmot MG: Prospective effect of job strain on general and central obesity in the Whitehall II Study. Am J Epidemio/ 2007, 165:828-837.

12. Block JP, He Y, Zaslavsky AM, Ding L, Ayanian JZ: Psychosocial stress and change in weight among US adults. Am J Epidemiol 2009, 170:181-192.

13. Korkeila M, Kaprio J, Rissanen A, Koshenvuo M, Sorensen TI: Predictors of major weight gain in adult Finns: stress, life satisfaction and personality traits. Int J Obes Relat Metab Disord 1998, 22:949-957.

14. Serlachius $A$, Hamer M, Wardle J: Stress and weight change in university students in the United Kingdom. Physiol Behav 2007, 92:548-553.

15. Straub RH: Systemic disease sequelae in chronic inflammatory diseases and chronic psychological stress - comparison and pathophysiological model. Ann N Y Acad Sci 2014, 1318:24-31

16. Liefmann R: Endocrine imbalance in rheumatoid arthritis and rheumatoid spondylitis; hyperglycemia unresponsiveness, insulin resistance, increased gluconeogenesis and mesenchymal tissue degeneration; preliminary report. Acta Med Scand 1949, 136:226-232.

17. Svenson $\mathrm{KL}$, Lundqvist G, Wide L, Hallgren R: Impaired glucose handling in active rheumatoid arthritis: relationship to the secretion of insulin and counter-regulatory hormones. Metabolism 1987, 36:940-943.

18. Dessein $\mathrm{PH}$, Joffe $\mathrm{BI}$ : Insulin resistance and impaired beta cell function in rheumatoid arthritis. Arthritis Rheum 2006, 54:2765-2775.

19. Tso TK, Huang HY, Chang CK, Liao YJ, Huang WN: Clinical evaluation of insulin resistance and beta-cell function by the homeostasis model assessment in patients with systemic lupus erythematosus. Clin Rheumatol 2004, 23:416-420.

20. Kiortsis DN, Mavridis AK, Vasakos S, Nikas SN, Drosos AA: Effects of infliximab treatment on insulin resistance in patients with rheumatoid arthritis and ankylosing spondylitis. Ann Rheum Dis 2005, 64:765-766.

21. Gonzalez-Gay MA, De Matias JM, Gonzalez-Juanatey C, Garcia-Porrua C, Sanchez-Andrade A, Martin J, Llorca J: Anti-tumor necrosis factor-alpha 
blockade improves insulin resistance in patients with rheumatoid arthritis. Clin Exp Rheumatol 2006, 24:83-86.

22. Kiortsis DN, Mavridis AK, Filippatos TD, Vasakos S, Nikas SN, Drosos AA: Effects of infliximab treatment on lipoprotein profile in patients with rheumatoid arthritis and ankylosing spondylitis. J Rheumato/ 2006, 33:921-923.

23. Dubreuil M, Rho YH, Man A, Zhu Y, Zhang Y, Love TJ, Ogdie A, Gelfand JM, Choi HK: Diabetes incidence in psoriatic arthritis, psoriasis and rheumatoid arthritis: a UK population-based cohort study. Rheumatology (Oxford) 2014, 53:346-352.

24. Yalow RS, Berson SA: Immunoassay of endogenous plasma insulin in man. J Clin Invest 1960, 39:1157-1175.

25. Randle PJ, Garland PB, Hales CN, Newsholme EA: The glucose fatty-acid cycle. Its role in insulin sensitivity and the metabolic disturbances of diabetes mellitus. Lancet 1963, 1:785-789.

26. Landsberg $L$ : Role of the sympathetic adrenal system in the pathogenesis of the insulin resistance syndrome. Ann N Y Acad Sci 1999, 892:84-90.

27. Landsberg L, Aronne LJ, Beilin LJ, Burke V, Igel LI, Lloyd-Jones D, Sowers J: Obesity-related hypertension: pathogenesis, cardiovascular risk, and treatment: a position paper of The Obesity Society and the American Society of Hypertension. J Clin Hypertens (Greenwich) 2013, 15:14-33.

28. Björntorp P: Neuroendocrine perturbations as a cause of insulin resistance. Diabetes Metab Res Rev 1999, 15:427-441.

29. Chrousos GP: The role of stress and the hypothalamic-pituitary-adrenal axis in the pathogenesis of the metabolic syndrome: neuro-endocrine and target tissue-related causes. Int J Obes Relat Metab Disord 2000, 24(Suppl 2):S50-S55.

30. Chrousos GP, Tsigos C: Annals of the New York Academy of Science: Stress, Obesity, and Metabolic Syndrome. Malden, MA: John Wiley \& Sons; 2006.

31. Myers MG, Jr, Olson DP: Central nervous system control of metabolism. Nature 2012, 491:357-363.

32. Kaaja R, Kujala S, Manhem K, Katzman P, Kibarskis A, Antikainen R, Yliharsila H, Erkkola R, Tuomilehto J: Effects of sympatholytic therapy on insulin sensitivity indices in hypertensive postmenopausal women. Int I Clin Pharmacol Ther 2007, 45:394-401.

33. Mahfoud F, Schlaich M, Kindermann I, Ukena C, Cremers B, Brandt MC, Hoppe UC, Vonend O, Rump LC, Sobotka PA, Krum H, Esler M, Bohm M: Effect of renal sympathetic denervation on glucose metabolism in patients with resistant hypertension: a pilot study. Circulation 2011, 123:1940-1946.

34. Hotamisligil GS, Shargill NS, Spiegelman BM: Adipose expression of tumor necrosis factor-alpha: direct role in obesity-linked insulin resistance. Science 1993, 259:87-91

35. Montague CT, Faroogi IS, Whitehead JP, Soos MA, Rau H, Wareham NJ, Sewter CP, Digby JE, Mohammed SN, Hurst JA, Cheetham CH, Earley AR, Barnett AH, Prins JB, O'Rahilly S: Congenital leptin deficiency is associated with severe early-onset obesity in humans. Nature 1997, 387:903-908.

36. Vaisse C, Clement K, Guy-Grand B, Froguel P: A frameshift mutation in human MC4R is associated with a dominant form of obesity. Nat Genet 1998, 20:113-114.

37. Peters A, Langemann D: Build-ups in the supply chain of the brain: on the neuroenergetic cause of obesity and type 2 diabetes mellitus. Front Neuroenergetics 2009, 1:2-12.

38. Jauch-Chara K, Oltmanns KM: Obesity - a neuropsychological disease? Systematic review and neuropsychological model. Prog Neurobiol 2014, 114C:84-101.

39. Keen-Rhinehart E, Ondek K, Schneider JE: Neuroendocrine regulation of appetitive ingestive behavior. Front Neurosci 2013, 7:213.

40. Osborn O, Olefsky JM: The cellular and signaling networks linking the immune system and metabolism in disease. Nat Med 2012, 18:363-374.

41. Shoelson SE, Herrero L, Naaz A: Obesity, inflammation, and insulin resistance. Gastroenterology 2007, 132:2169-2180.

42. Nakae J, Oki M, Cao Y: The FoxO transcription factors and metabolic regulation. FEBS Lett 2008, 582:54-67.

43. Goldfine AB, Fonseca V, Jablonski KA, Pyle L, Staten MA, Shoelson SE: The effects of salsalate on glycemic control in patients with type 2 diabetes: a randomized trial. Ann Intern Med 2010, 152:346-357.

44. Stagakis I, Bertsias G, Karvounaris S, Kavousanaki M, Virla D, Raptopoulou A, Kardassis D, Boumpas DT, Sidiropoulos PI: Anti-tumor necrosis factor therapy improves insulin resistance, beta cell function and insulin signaling in active rheumatoid arthritis patients with high insulin resistance. Arthritis Res Ther 2012, 14:R141.

45. Schultz O, Oberhauser F, Saech J, Rubbert-Roth A, Hahn M, Krone W, Laudes
M: Effects of inhibition of interleukin-6 signalling on insulin sensitivity and lipoprotein (a) levels in human subjects with rheumatoid diseases. PLoS One 2010, 5:e14328.

46. Glass CK, Olefsky JM: Inflammation and lipid signaling in the etiology of insulin resistance. Cell Metab 2012, 15:635-645.

47. Ley RE, Turnbaugh PJ, Klein S, Gordon Jl: Microbial ecology: human gut microbes associated with obesity. Nature 2006, 444:1022-1023.

48. Johnson AM, Olefsky JM: The origins and drivers of insulin resistance. Cell 2013, 152:673-684

49. Jin C, Henao-Mejia J, Flavell RA: Innate immune receptors: key regulators of metabolic disease progression. Cell Metab 2013, 17:873-882.

50. Neel JV: Diabetes mellitus: a'thrifty' genotype rendered detrimental by 'progress'? Am J Hum Genet 1962, 14:353-362.

51. Neel JV: The 'thrifty genotype' in 1998. Nutr Rev 1999, 57:S2-S9

52. Reaven GM: Hypothesis: muscle insulin resistance is the ('not-so') thrifty genotype. Diabetologia 1998, 41:482-484.

53. Levitan RD, Wendland B: Novel 'thrifty' models of increased eating behaviour. Curr Psychiatry Rep 2013, 15:408.

54. Cahill GF, Jr: Human evolution and insulin-dependent (IDD) and noninsulin dependent diabetes (NIDD). Metabolism 1979, 28:389-393.

55. Hales CN, Barker DJ: The thrifty phenotype hypothesis. Br Med Bull 2001, $60: 5-20$.

56. Hales CN, Barker DJ: Type 2 (non-insulin-dependent) diabetes mellitus: the thrifty phenotype hypothesis. Diabetologia 1992, 35:595-601.

57. Spalding KL, Arner E, Westermark PO, Bernard S, Buchholz BA, Bergmann O, Blomqvist L, Hoffstedt J, Naslund E, Britton T, Concha H, Hassan M, Ryden M, Frisen J, Arner P: Dynamics of fat cell turnover in humans. Nature 2008, 453:783-787.

58. Sebert S, Sharkey D, Budge H, Symonds ME: The early programming of metabolic health: is epigenetic setting the missing link? Am J Clin Nutr 2011, 94:1953S-1958S.

59. Roseboom TJ, Watson ED: The next generation of disease risk: are the effects of prenatal nutrition transmitted across generations? Evidence from animal and human studies. Placenta 2012, 33(Suppl 2):e40-e44.

60. Gluckman PD, Hanson MA: The developmental origins of the metabolic syndrome. Trends Endocrinol Metab 2004, 15:183-187.

61. Fernandez-Real JM, Ricart W: Insulin resistance and inflammation in an evolutionary perspective: the contribution of cytokine genotype/ phenotype to thriftiness. Diabetologia 1999, 42:1367-1374.

62. Hotamisligil GS: Inflammation and metabolic disorders. Nature 2006 444:860-867.

63. Kitano H, Oda K, Kimura T, Matsuoka Y, Csete M, Doyle J, Muramatsu M: Metabolic syndrome and robustness tradeoffs. Diabetes 2004, 53(Suppl 3):S6-S15.

64. Schwartz MW, Niswender KD: Adiposity signaling and biological defense against weight gain: absence of protection or central hormone resistance? J Clin Endocrinol Metab 2004, 89:5889-5897.

65. Taubes G: Treat obesity as physiology, not physics. Nature 2012, 492:155.

66. Kuipers RS, Luxwolda MF, jck-Brouwer DA, Eaton SB, Crawford MA, Cordain L, Muskiet FA: Estimated macronutrient and fatty acid intakes from an East African Paleolithic diet. Br J Nutr 2010, 104:1666-1687.

67. Calder PC, Dimitriadis G, Newsholme P: Glucose metabolism in lymphoid and inflammatory cells and tissues. Curr Opin Clin Nutr Metab Care 2007. 10:531-540

68. DeFronzo RA: Banting Lecture. From the triumvirate to the ominous octet: a new paradigm for the treatment of type 2 diabetes mellitus. Diabetes 2009, 58:773-795.

69. Blaxter K: Energy Metabolism in Animals and Man. Cambridge: Cambridge University Press; 1989.

70. Straub RH, Cutolo M, Buttgereit F, Pongratz G: Energy regulation and neuroendocrine-immune control in chronic inflammatory diseases. J Intern Med 2010, 267:543-560.

71. Geigy Pharmazeutika: Wissenschaftliche Tabellen. Wehr: Ciba-Geigy; 1973

72. Peters A, Schweiger U, Pellerin L, Hubold C, Oltmanns KM, Conrad M, Schultes B, Born J, Fehm HL: The selfish brain: competition for energy resources. Neurosci Biobehav Rev 2004, 28:143-180.

73. Straub RH: Evolutionary medicine and chronic inflammatory state - known and new concepts in pathophysiology. J Mol Med 2012, 90:523-534.

74. Quine S, Lyle D, Pierce J: Stressors experienced by relatives of patients in an innovative rehabilitation program. Health Soc Work 1993, 18:1 14-122.

75. McAlonan GM, Lee AM, Cheung V, Cheung C, Tsang KW, Sham PC, Chua SE, 
Wong JG: Immediate and sustained psychological impact of an emerging infectious disease outbreak on health care workers. Can J Psychiatry 2007 52:241-247.

76. Zunhammer M, Eberle H, Eichhammer P, Busch V: Somatic symptoms evoked by exam stress in university students: the role of alexithymia, neuroticism, anxiety and depression. PLoS One 2013, 8:e84911.

77. Borella P, Bargellini A, Rovesti S, Pinelli M, Vivoli R, Solfrini V, Vivoli G: Emotional stability, anxiety, and natural killer activity under examination stress. Psychoneuroendocrinology 1999, 24:613-627.

78. Hitze B, Hubold C, van DR, Schlichting K, Lehnert H, Entringer S, Peters A: How the selfish brain organizes its supply and demand. Front Neuroenergetics 2010, 2:7-17.

79. Aggarwal B, Liao M, Christian A, Mosca L: Influence of caregiving on lifestyle and psychosocial risk factors among family members of patients hospitalized with cardiovascular disease. J Gen Intern Med 2009, 24:93-98.

80. Fredman L, Doros G, Cauley JA, Hillier TA, Hochberg MC: Caregiving, metabolic syndrome indicators, and 1-year decline in walking speed: results of Caregiver-SOF. J Gerontol A Biol Sci Med Sci 2010, 65:565-572.

81. von Känel R, Mausbach BT, Dimsdale JE, Mills PJ, Patterson TL, ncoli-Israel S, Ziegler MG, Roepke SK, Chattillion EA, Allison M, Grant I: Cardiometabolic effects in caregivers of nursing home placement and death of their spouse with Alzheimer's disease. J Am Geriatr Soc 2011, 59:2037-2044.

82. Reeves KW, Bacon K, Fredman L: Caregiving associated with selected cancer risk behaviors and screening utilization among women: cross-sectional results of the 2009 BRFSS. BMC Public Health 2012, 12:685.

83. Capistrant BD, Berkman LF, Glymour MM: Does duration of spousal caregiving affect risk of depression onset? Evidence from the health and retirement study. Am J Geriatr Psychiatry 2014, 22:766-770

84. Kiecolt-Glaser JK, Preacher KJ, MacCallum RC, Atkinson C, Malarkey WB, Glaser $\mathrm{R}$ : Chronic stress and age-related increases in the proinflammatory cytokine IL-6. Proc Natl Acad Sci U S A 2003, 100:9090-9095.

85. Agardh EE, Ahlbom A, Andersson T, Efendic S, Grill V, Hallqvist J, Norman A, Ostenson CG: Work stress and low sense of coherence is associated with type 2 diabetes in middle-aged Swedish women. Diabetes Care 2003, 26:719-724.

86. Esquirol Y, Bongard V, Mabile L, Jonnier B, Soulat JM, Perret B: Shift work and metabolic syndrome: respective impacts of job strain, physical activity, and dietary rhythms. Chronobiol Int 2009, 26:544-559.

87. Edwards EM, Stuver SO, Heeren TC, Fredman L: Job strain and incident metabolic syndrome over 5 years of follow-up: the coronary artery risk development in young adults study. J Occup Environ Med 2012 54:1447-1452

88. Mullington JM, Haack M, Toth M, Serrador JM, Meier-Ewert HK: Cardiovascular, inflammatory, and metabolic consequences of sleep deprivation. Prog Cardiovasc Dis 2009, 51:294-302.

89. Kivimaki M, Virtanen M, Elovainio M, Kouvonen A, Vaananen A, Vahtera J: Work stress in the etiology of coronary heart disease - a meta-analysis. Scand J Work Environ Health 2006, 32:431-442.

90. Meyer-Hermann ME, Maini PK: Cutting edge: back to 'one-way' germinal centers. J Immunol 2005, 174:2489-2493.

91. Boyer D, Walsh PD: Modelling the mobility of living organisms in heterogeneous landscapes: does memory improve foraging success? Philos Trans A Math Phys Eng Sci 2010, 368:5645-5659.

92. Nairne JS, Pandeirada JN: Adaptive memory: ancestral priorities and the mnemonic value of survival processing. Cogn Psychol 2010, 61:1-22.

93. Fall T, Ingelsson E: Genome-wide association studies of obesity and metabolic syndrome. Mol Cell Endocrinol 2014, 382:740-757.

94. Kuzawa CW: Adipose tissue in human infancy and childhood: an evolutionary perspective. Am J Phys Anthropol 1998, 107(Suppl 27):177-209.

95. Aletaha D, Neogi T, Silman AJ, Funovits J, Felson DT, Bingham CO, III, Birnbaum NS, Burmester GR, Bykerk VP, Cohen MD, Combe B, Costenbader KH, Dougados M, Emery P, Ferraccioli G, Hazes JM, Hobbs K, Huizinga TW, Kavanaugh A, Kay J, Kvien TK, Laing T, Mease P, Menard HA, Moreland LW, Naden RL, Pincus T, Smolen JS, Stanislawska-Biernat E, Symmons D, et al:: 2010 Rheumatoid arthritis classification criteria: an American College of Rheumatology/European League Against Rheumatism collaborative initiative. Arthritis Rheum 2010, 62:2569-2581.

96. Björntorp P: Thrifty genes and human obesity. Are we chasing ghosts? Lancet 2001, 358:1006-1008.

97. Ferrer B, Navia B, Giralt M, Comes G, Carrasco J, Molinero A, Quintana A
Senaris RM, Hidalgo J: Muscle-specific interleukin- 6 deletion influences body weight and body fat in a sex-dependent manner. Brain Behav Immun 2014, 40:121-130.

98. Tsigos C, Papanicolaou DA, Defensor R, Mitsiadis CS, Kyrou I, Chrousos GP: Dose effects of recombinant human interleukin- 6 on pituitary hormone secretion and energy expenditure. Neuroendocrinology 1997, 66:54-62.

99. Straub RH, Konecna L, Hrach S, Rothe G, Kreutz M, Schölmerich J, Falk W, Lang B: Serum dehydroepiandrosterone (DHEA) and DHEA sulfate are negatively correlated with serum interleukin-6 (IL-6), and DHEA inhibits IL-6 secretion from mononuclear cells in man in vitro: possible link between endocrinosenescence and immunosenescence. J Clin Endocrinol Metab 1998, 83:2012-2017.

100. Straub RH, Paimela L, Peltomaa R, Schölmerich J, Leirisalo-Repo M: Inadequately low serum levels of steroid hormones in relation to IL-6 and TNF in untreated patients with early rheumatoid arthritis and reactive arthritis. Arthritis Rheum 2002, 46:654-662.

101. Lutgendorf SK, Garand L, Buckwalter KC, Reimer TT, Hong SY, Lubaroff DM: Life stress, mood disturbance, and elevated interleukin- 6 in healthy older women. J Gerontol A Biol Sci Med Sci 1999, 54:M434-M439.

102. Sjögren $E$, Leanderson P, Kristenson M, Ernerudh J: Interleukin-6 levels in relation to psychosocial factors: studies on serum, saliva, and in vitro production by blood mononuclear cells. Brain Behav Immun 2006 20:270-278.

103. Müller N, Riedel M, Scheppach C, Brandstätter B, Sokullu S, Krampe K, Ulmschneider M, Engel RR, Möller HJ, Schwarz MJ: Beneficial antipsychotic effects of celecoxib add-on therapy compared to risperidone alone in schizophrenia. Am J Psychiatry 2002, 159:1029-1034.

104. Rosenblat JD, Cha DS, Mansur RB, McIntyre RS: Inflamed moods: a review of the interactions between inflammation and mood disorders. Prog Neuropsychopharmacol Biol Psychiatry 2014, 53:23-34.

105. Müller N: The role of anti-inflammatory treatment in psychiatric disorders. Psychiatr Danub 2013, 25:292-298

106. Himsworth HP: Diabetres mellitus: its differentiation into insulin-sensitive and insulin-insensitive types. Lancet 1936, 227:127-130.

107. Thomsen V: Das Trauma und der Kohlenhydratstoffwechsel. Acta Med Scand 1936, 90:918-925.

108. Graham G: A review of the causes of diabetes mellitus. Br Med J 1940 2:479-482

109. Arendt EC, Pattee CJ: Studies on obesity. I. The insulin-glucose tolerance curve. J Clin Endocrinol Metab 1956, 16:367-374

110. Collins J: Insulin resistance in schizophrenia. Med J Aust 1957, 44:467-470.

111. van Praag HM, Leijnse B: Depression, glucose tolerance, peripheral glucose uptake and their alterations under the influence of anti-depressive drugs of the hydrazine type. Psychopharmacologia 1965, 8:67-78.

112. Butterfield WJH, Wichelow MJ: Peripheral glucose metabolism in control subjects and diabetic patients during glucose, glucose-insulin and insulin sensitivity tests. Diabetologia 1965, 1:43-53.

113. Shen SW, Reaven GM, Farquhar JW: Comparison of impedance to insulinmediated glucose uptake in normal subjects and in subjects with latent diabetes. J Clin Invest 1970, 49:2151-2160.

114. DeFronzo RA, Tobin JD, Andres R: Glucose clamp technique: a method for quantifying insulin secretion and resistance. Am J Physiol 1979, 237:E214-E223.

115. Wolfe RR: Substrate utilization/insulin resistance in sepsis/trauma. Baillieres Clin Endocrinol Metab 1997, 11:645-657.

116. Kasuga M, ZickY, Blithe DL, Crettaz M, Kahn CR: Insulin stimulates tyrosine phosphorylation of the insulin receptor in a cell-free system. Nature 1982 298:667-669.

117. Ciaraldi TP, Kolterman OG, Scarlett JA, Kao M, Olefsky JM: Role of glucose transport in the postreceptor defect of non-insulin-dependent diabetes mellitus. Diabetes 1982, 31:1016-1022

118. Grunberger G, Zick Y, Gorden P: Defect in phosphorylation of insulin receptors in cells from an insulin-resistant patient with normal insulin binding. Science 1984, 223:932-934.

119. Garvey WT, Olefsky JM, Marshall S: Insulin induces progressive insulin resistance in cultured rat adipocytes. Sequential effects at receptor and multiple postreceptor sites. Diabetes 1986, 35:258-267.

120. Krieger DR, Landsberg L: Mechanisms in obesity-related hypertension: role of insulin and catecholamines. Am J Hypertens 1988, 1:84-90.

121. DeFronzo RA: Lilly lecture 1987. The triumvirate: beta-cell, muscle, liver. A collusion responsible for NIDDM. Diabetes 1988, 37:667-687. 
122. Reaven GM: Banting lecture 1988. Role of insulin resistance in human disease. Diabetes 1988, 37:1595-1607.

123. Uchida I, Asoh T, Shirasaka C, Tsuji H: Effect of epidural analgesia on postoperative insulin resistance as evaluated by insulin clamp technique. Br J Surg 1988, 75:557-562

124. Greisen J, Juhl CB, Grofte T, Vilstrup H, Jensen TS, Schmitz O: Acute pain induces insulin resistance in humans. Anesthesiology 2001, 95:578-584.

125. Feingold KR, Grunfeld C: Role of cytokines in inducing hyperlipidemia. Diabetes 1992, 41(Suppl 2):97-101.

126. Moberg E, Kollind M, Lins PE, Adamson U: Acute mental stress impairs insulin sensitivity in IDDM patients. Diabetologia 1994, 37:247-251.

127. Keltikangas-Jarvinen L, Ravaja N, Raikkonen K, Lyytinen H: Insulin resistance syndrome and autonomically mediated physiological responses to experimentally induced mental stress in adolescent boys. Metabolism 1996, 45:614-621.

128. Seematter G, Guenat E, Schneiter P, Cayeux C, Jequier E, Tappy L: Effects of mental stress on insulin-mediated glucose metabolism and energy expenditure in lean and obese women. Am J Physiol Endocrinol Metab 2000, 279:E799-E805.

129. Larsen CM, Faulenbach M, Vaag A, Volund A, Ehses JA, Seifert B, MandrupPoulsen T, Donath MY: Interleukin-1-receptor antagonist in type 2 diabetes mellitus. N Engl J Med 2007, 356:1517-1526.

130. Fleischman A, Shoelson SE, Bernier R, Goldfine AB: Salsalate improves glycemia and inflammatory parameters in obese young adults. Diabetes Care 2008, 31:289-294.

131. DIAbetes Genetics Replication And Meta-analysis (DIAGRAM) Consortium; Mahajan A, Go MJ, Zhang W, Below JE, Gaulton KJ, Ferreira T, Horikoshi M, Johnson AD, Ng MC, Prokopenko I, Saleheen D, Wang X, Zeggini E, Abecasis GR, Adair LS, Almgren P, Atalay M, Aung T, Baldassarre D, Balkau B, Bao Y, Barnett AH, Barroso I, Basit A, Been LF, Beilby J, Bell Gl, Benediktsson R, Bergman RN, et al:: Genome-wide trans-ancestry meta-analysis provides insight into the genetic architecture of type 2 diabetes susceptibility. Nat Genet 2014, 46:234-244.

132. Bergman RN, Ider YZ, Bowden CR, Cobelli C: Quantitative estimation of insulin sensitivity. Am J Physiol 1979, 236:E667-E677.

133. Borai A, Livingstone C, Kaddam I, Ferns G: Selection of the appropriate method for the assessment of insulin resistance. BMC Med Res Methodol 2011, 11:158.
134. Abdul-Ghani MA, Matsuda M, Balas B, DeFronzo RA: Muscle and liver insulin resistance indexes derived from the oral glucose tolerance test. Diabetes Care 2007, 30:89-94

135. Syed Ikmal SI, Zaman HH, Vethakkan SR, Wan Ahmad WA: Potential biomarkers of insulin resistance and atherosclerosis in type 2 diabetes mellitus patients with coronary artery disease. Int J Endocrinol 2013, 2013:698567.

136. Rassow J, Hauser K, Netzker R, Deutzmann R: Biochemistry. Stuttgart: Georg Thieme; 2008.

137. lemitsu M, Itoh M, Fujimoto T, Tashiro M, Nagatomi R, Ohmori H, Ishii K: Whole-body energy mapping under physical exercise using positron emission tomography. Med Sci Sports Exerc 2000, 32:2067-2070.

138. Rolfe DF, Brown GC: Cellular energy utilization and molecular origin of standard metabolic rate in mammals. Physio/ Rev 1997, 77:731-758.

139. Pabst $R$, Trepel F: 72-hour perfusion of the isolated spleen at normothermia. Res Exp Med (Berl) 1974, 164:247-257.

140. Edwards C: Sixty years after Hench - corticosteroids and chronic inflammatory disease. J Clin Endocrinol Metab 2012, 97:1443-1451.

141. Ehrhart-Bornstein M, Hinson JP, Bornstein SR, Scherbaum WA, Vinson GP: Intraadrenal interactions in the regulation of adrenocortical steroidogenesis. Endocr Rev 1998, 19:101-143.

142. Castagnetta LA, Carruba G, Granata OM, Stefano R, Miele M, Schmidt M, Cutolo M, Straub RH: Increased estrogen formation and estrogen to androgen ratio in the synovial fluid of patients with rheumatoid arthritis. J Rheumatol 2003, 30:2597-2605.

143. Capellino S, Cosentino M, Wolff C, Schmidt M, Grifka J, Straub RH: Catecholamine-producing cells in the synovial tissue during arthritis: modulation of sympathetic neurotransmitters as new therapeutic target. Ann Rheum Dis 2010, 69:1853-1860.

144. Pongratz G, Straub RH: Role of peripheral nerve fibres in acute and chronic inflammation in arthritis. Nat Rev Rheumatol 2013, 9:117-126.

\section{doi:10.1186/ar4688}

Cite this article as: Straub RH: Insulin resistance, selfish brain, and selfish immune system: an evolutionarily positively selected program used in chronic inflammatory diseases. Arthritis Research \& Therapy 2014 16(Suppl 2):S4 